\title{
Integrációs dilemmák a magyarországi NEET populációval kapcsolatban
}

\section{Integration dilemmas relating to the Hungarian NEET group}

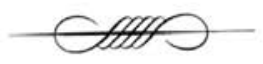

\begin{abstract}
This paper focuses on a particularly vulnerable group of young people within the contemporary Hungarian society, so called: NEET (Not in Employment, Education or Training).

On those youngsters who are unemployed, and not taking part in any education or training system.

In this work, the author tries to put into words his own integration dilemmas relating to the Hungarian NEET group. The thinking was basically guided by a study of KovÁCH et al. (2016), The integration and stratification models of Hungarian society. Some stratification models were researched in that study and in this paper some of these will be com-pared with the Hungarian NEET, the work tries to identify their possible positions in the different models, and reflects on some dilemmas relating to the integration of the Hungarian NEET group.

The present research focuses on three stratification models: occupational groups, status groups and latent classes, then on the integration/disintegration model.

The study tries to place the Hungarian NEET group in the first three models, and reflects on their situation then, looking at the integration/disintegration model, draws conclusions on the integrability of the Hungarian NEET group.
\end{abstract}

\section{KEYWORDS}

NEET; integration; disintegration; re-integration; social exclusion

DOI 10.14232/belv.2018.1.8 https://doi.org/10.14232/belv.2018.1.8

Cikkre való hivatkozás / How to cite this article: Sánta, Tamás (2018): Integrációs dilemmák a magyarországi NEET populációval kapcsolatban. Belvedere Meridionale 30. évf. 1. sz.127-145. pp.

ISSN 1419-0222 (print) ISSN 2064-5929 (online, pdf)

(Creative Commons) Nevezd meg! - Így add tovább! 4.0 (CC BY-SA 4.0)

(Creative Commons) Attribution-ShareAlike 4.0 International (CC BY-SA 4.0)

www.belvedere-meridionale.hu 


\section{KATEGÓRIÁK A NEET CSOPORTON BELÜL ${ }^{1}$}

Elöljáróban az talán magabiztosan leszögezhető, hogy a NEET fiatalok egy dezintegrált csoportnak tekinthetők a mai magyar társadalomban. Sőt, integrálásukra történtek már és történnek kísérletek Magyarországon. Ennek egyik, talán legszemléletesebb példája a 2015-ben Európai Uniós indíttatásra és támogatásra elindult Ifjúsági Garancia Program, mely ennek a csoportnak egy részét (a regisztrált NEET-eseket) veszi górcső alá egy integrációs folyamat keretében. (kormany.hu)

Ahhoz, hogy a fenti állításomat bizonyítsam, további megállapításokat szükséges tenni. A NEET-es fiatalok közössége nem homogén csoport. (AUDiT CoMMission 2010.) A minél pontosabb fogalmi lehatárolás érdekében alapvető különbségek tehetők. A NEET-esek egyrészt nem azonosak a fiatal munkanélküliek csoportjával, még akkor sem, ha jelentős átfedés található közöttük. Ugyanakkor munkaerő-piaci kontextusban a NEET fogalma akár jelentősebben is változhat a különböző nemzetközi szervezetek megközelítésében. (ELDER 2015.)

Másrészt, szükséges megkülönböztetni a nem-veszélyeztetett (vagy kevésbé veszélyeztetett) valamint a kifejezetten veszélyetetett tagokat a NEET csoporton belül, illetve ezek alcsoportjait. Ez az alapvető csoportosítás jelöli ki a dezintegrált csoportot a NEET-es fiatalokon belül.

A NEET csoportban kevésbé veszélyeztetett tagoknak tekinthetők azok a fiatalok, akik középiskolai tanulmányaikat befejezték, és sikeres felvételi vizsgát tettek egy felsőfokú intézménybe, s várják, hogy tanulmányaikat folytathassák. Ide sorolhatóak azok a személyek is, akik a középiskolai vagy a felsőfokú tanulmányaikat befejezték, sikeresen megpályáztak egy állást, s most abban az átmeneti időszakban NEET-esek, míg munkába nem állnak. Továbbá ide tartoznak azok is - bár a magyarországi viszonyokat figyelembe véve számuk elenyésző lehet -, akik tanulmányaikat ugyan befejezték, de munkába még nem kívánnak állni, bár lenne lehetőségük, s ezt a tudatosan vállalt átmeneti időszakot például utazással egybekötött tapasztalatszerzéssel töltik. S végül még egy csoportba sorolható az általam nem vagy kevésbé veszélyeztetett NEET kategóriába azok a fiatalok, akik NEET-esek ugyan, de az ebből a státuszból fakadó idejüket és energiájukat önkéntesi munkákba csatornázzák be. Ugyan a szakirodalom említi ezt a kategóriát (EUROFOUND 2016.), de a kutatásaim jelenlegi fázisában a hazai viszonyok között nem tudok erre példát mondani.

A fentebb kiemelt kategóriák mindegyike lehet olyan NEET státusz, amely tulajdonképpen választott, rövid ideig tart, s éppen azért, mert választott, nem is tekinthető veszélyeztetettnek. Ehhez a választott státuszhoz, véleményem szerint, mindenképpen szükséges hozzákapcsolni a családi hátteret, azt a létkörülményt, melyben egy fiatal tudatosan választhatja, akár rövidebb, akár hosszabb ideig ezt a létállapotot, s amelynek fenntartását ez a környezet biztosít(hat)ja. Ebben az értelemben tehát a dezintegráltság nem áll fent erre a NEET kategóriára (s tulajdonképpen maga a NEET kifejezés sem a legmegfelelőbb, sőt bizonyos körülmények között akár még diszkrimináló is lehet).

Az természetesen felvetődhet, hogy mi történik abban az esetben, ha a fiatal ugyan felvételit nyert, de valamilyen oknál fogva mégsem kezdheti meg felsőfokú tanulmányait. Vagy azt a visszajelzést kapta leendő munkaadójától, hogy a megpályázott állásra felvették, de valami mégis közbejön, s a munkalehetőség elillan. Nos, ebben az esetben ez a szituáció(k) már nem választott, $\mathrm{s}$ a fiatal a veszélyeztetett NEET státusznak tagjává válhat. $\mathrm{S}$ ami ezután történik, vagy történhet

\footnotetext{
${ }^{1}$ Az ebben a szerkezeti egységben tárgyaltak egy része korábbi publikált munkáimban már megjelentek. A téma bevezetőjeként azonban fontosnak tartottam, hogy részben, illetve módosítva, kiegészítve a korábban leírtakat, itt egy önálló fejezetként jelenjen meg. ST.
} 
vele, fogja nagymértékben meghatározni, hogy dezintegrálttá válik-e. Vagyis ebben az esetben a dezintegráció sokkal inkább egy folyamatként fogható fel, mintsem egy statikus állapotként.

Úgy vélem, a NEET lét lehet egyfajta választott státusz is, de ehhez mindenképpen szükséges egy anyagilag is biztonságos háttér; feltételezem, ez a választás csak rövid ideig tart, $\mathrm{s}$ talán éppen ezek miatt nem is szükséges a NEET címke használata ezekben az esetekben.

Egy brit tanulmány részletes csoportbontást közölt az igazán veszélyeztetett NEET csoport köréről. (COLES et al. 2010.) A szerzők a 16-18 éves korosztály rizikófaktorait sorolták fel, de úgy gondolom, az általuk felsoroltak minden további nélkül alkalmazhatók a teljes NEET korcsoportra. Ezek szerint azok a NEET-be tartozó fiatalok különösen veszélyeztetettek, akik(nek):

- szülei szegények és munkanélküliek,

- deprivált körülmények között élnek és az átlagos iskolai teljesítményük alacsony volt,

- gondozásra szorulnak,

- fiatalon estek teherbe, vagy váltak szülővé,

- fogyatékkal élők,

- speciális oktatási igényeik vannak,

- fiatalon arra kényszerülnek, hogy valamely családtagjukat gondozzák,

- hajléktalanok,

- mentális betegségben szenvednek,

- drog vagy alkohol problémával küzdenek,

- valamilyen jogsértő tevékenységet folytattak,

- iskolakerülők, vagy valamilyen okból kizártak tanulmányuk folytatásából,

- gyenge, vagy semmilyen képzettségük sincs 16 éves korukra,

- tanulmányaikat végleg befejezték tankötelezettségi koruk után.

Az Európai Unió 2013-as munkaerő-piaci felmérése alapján a fenti kategóriákat már „,csak” hétre redukálta, de ezek is nagymértékű hasonlóságokat mutatnak az említett felsorolással. (EUROFOUND 2016.)

- visszatérők a munkaerő-piacra, vagy az oktatásba,

- rövid ideig munkanélküliek,

- tartósan munkanélküliek,

- passzívak,

- fogyatékkal élő fiatalok,

- családi kötelezettségek (gondozás, ápolás) terhei alatt élők,

- egyéb, a fenti hat kategóriába nem sorolható NEET-es.

Úgy vélem, a negyedik és az utolsó kategória igényelhet némi magyarázatot. A passzív NEET-esek (discouraged) csoportjába azok a fiatalok tartoznak, akik már nem is keresnek munkalehetőségeket, mivel úgy gondolják, számukra nincsenek is lehetőségek. Ezt a csoportot veszélyezteti talán leginkább a társadalmi kirekesztődés, illetve a folyamatos és tartós (akár egész életen át tartó) munkanélküliség. (EUROFOUND 2016.) 
Az ,egyéb” kategóriába tartozhatnak a már általam is korábban említett kevésbé veszélyeztetett NEET csoport tagjai. Továbbá azok a fiatalok is, akik NEET-esek, de vállalnak önkéntesi munkákat. (EuROFOUND 2016.) Ugyanakkor ebbe a kategóriába tartoznak azok a fiatalok is, akik NEET-esek, de nem kerülnek be a szolgáltató rendszerek látóterébe, vagyis gyakorlatilag nem tudunk róluk semmit sem.

Az alkategóriákat egyetlen jellemzővel lehetne illetni: a depriváció valamilyen foka jellemzi őket. Eddigi kutatásaim szerint a NEET-es fiatalok jelentős többsége szegény körülmények között élő családok gyermekei. Ott, ahol a szegénység egyik oka az egyik, vagy mindkét szülő munkanélkülisége, vagy tartós munkanélkülisége. Ott, ahol a fiatal úgy nő fel, hogy adott esetben vagy az egyik szülőjét, vagy mindkét szülőjét nem is látta hivatalosan bejelentett munkahelyen dolgozni. Ahol azt tanulhatta meg, hogy nincs is lehetőség a bejelentett munkára, csak feketemunka létezik. Vagy a bejelentett munka (például a közmunka) kiszolgáltatott státuszra predesztinál, s akkor van, ha az elvárt ,, viselkedési formának” megfelel a munkát vállalni akaró. Ahol már a szülőknek sem volt kielégítő az iskolai végzettsége, s az oktatás nem is képviselt értéket. Ebből kifolyólag a tanulás vagy a továbbtanulás, mint választott lehetőség vagy fel sem merül, vagy az értékrend legalsó rétegeiben húzódik meg.

Ebben a szocializációs háttérben felnövekvő fiatal számára a valószínűsíthető NEET lét már nem választott, sokkal inkább egy készen kapott státusz.

\section{Mit Jelent AZ INTEGRÁCió? Mit Jelent INTEGRÁltnAK LENNi?}

A következőkben az integráció fogalmára keresem a választ. Az integráció fogalmával, egyben megadható annak ellentéte is, a nem-integráció, vagy dezintegráció, mely véleményem szerint, nagymértékben jellemzi a NEET csoport tagjait.

DUPCSIK szerint (2012) az integráció fogalma az egyik leggyakrabban használt fogalom a szociológiában, sőt nem csak a szaktudomány területén, de komoly elterjedtsége van a köznapi nyelvhasználatban is.

A fogalom egyszerre utal a társadalomtudományok alapkérdéseire, vagyis hogyan müködik maga a társadalom. Ugyanakkor megmutat konkrét társadalmi mechanizmusokat is, vagyis hogyan „, illeszkednek be X-ek Y terülten”. (DuPCSIK 2012. 243.) Követve Dupcsik megállapításait, véleményem szerint tehát az integráció azt mutatja, hogyan müködik egy társadalom, illetve, ha nincs integráció, akkor ez azt jelentheti, hogy maga a társadalom nem müködik megfelelően. Továbbá, ha létezik az integráció, vagyis működőképes a társadalom, akkor az integrációs folyamat konkrétan mutat meg különböző mechanizmusokat, hogy a társadalom tagjai, hogyan és milyen formában integráltak a müködő társadalom egyes területeibe. Vagyis az integráció egy működő társadalom attribútuma és egyben egy meghatározó folyamat, mely a társadalom működését garantálhatja.

Az integráció folyamatában különböző együttmúködések figyelhetőek meg a társadalom egyes szereplői részéről. Erről az együttmüködésről KovÁcH et al. (2016) a következőket mondja: „,müködö társadalmi integráció esetén az egyén vagy intézmény úgy müködik együtt egy csoporttal, vagy egy nagyobb közösséggel, hogy részben elfogadja azok értékeit és normáit, és e normák és szabályok átláthatóak, elfogadottak és legitimek”. (p. 5) Ebben az együttmüködési folyamatban 
tehát, az integrálódó személy, vagy közösség számára ismertek a már integrált nagyobb közösség (társadalom?) értékei, normái és szabályai, sőt azokat az integrálódó személy átlátja, és legitimnek fogadja el. Az integráció, FERGE szerint (1990), a társadalmi újratermelés folyamatosságának feltétele. Vagyis e meghatározások felételezik, hogy az integrációt és annak folyamatát az integrálódó személy, vagy közösség ismeri, abban részt kíván venni. Továbbá, hogy a már integráltnak nevezett csoport normáit, szabályait átlátja, azokat legitimnek fogadja el, és ennek az integrált csoportnak az értékeit részben el is fogadja. Amennyiben ez megtörténik, és az integrálódó személy, vagy közösség az integráció folyamatában sikeresen részt vesz, és tagjává válik ennek a már integrálódott közösségnek, akkor a társadalom újratermelődik.

Ha azonban ennek a folyamatnak valamelyik fázisa, vagy maga a teljes folyamat el sem indul, vagy megtörik valahol, akkor az integrálódni kívánó személy, vagy közösség nem lesz integrált a nagyobb közösségbe (társadalomba?), helyette dezintegrált lesz.

Az integrációs modellnek, KovÁCH et al. szerint (2016) három szintje különböztethető meg. Az első a Habermas-i és Giddens-i elméleten alapuló rendszerintegráció. Ez alatt a kutatók olyan integrációs mechanizmusokat értenek, melyek a szubjektumtól független rendszerek működésének következményeként összehangolják a társadalom tagjainak ismétlődő cselekvéseit. Vagyis a társadalomban működnek az integrálódni kívánó szubjektumoktól független rendszerek (ilyen lehet például a gyermekjóléti rendszer, az oktatási rendszer, stb.), melyek összehangolják ezen szubjektumok ismétlődő cselekvéseit különböző integrációs mechanizmusok segítségével (például: a kialakított, többlépcsős, éveken át tartó kötelező oktatási rendszer).

Második a társadalmi szintű integráció. A tanulmány szerzői a Habermas-i életvilág analógiájára ide tartozónak fogják fel a kulturális újratermelés, a szocializáció, a bizalom, a részvétel és a közösséghez tartozás folyamatait. (p. 6.) Ebből a második szintből a dolgozat tárgyára vonatkozóan a szocializációt emelném ki, mint a társadalmi szintű integráció, szerintem, talán legfontosabb elemét a NEET-es fiatalokra vonatkoztatva.

A harmadikat a kutatók személyközi integrációnak nevezik. (p. 6.) Ennek az integrációnak alapja a személyközi kapcsolatok, illetve ehhez hozzáteszem, ezen személyközi kapcsolatok minősége és mennyisége, amelyek a rendszerintegrációs folyamatokhoz biztosíthatnak jelentős erőforrásokat. Vagyis, ha az integrációs folyamatokban résztvevő, integrálódni kívánó szubjektum rendelkezik megfelelő minőségű személyközi kapcsolatokkal, ez jelentősen befolyásolhatja a rendszerintegrációs folyamatait. Tehát egy NEET-es fiatalnak a személyközi kapcsolatai nagymértékben befolyásolják, hogy milyen, tőle független rendszerekhez tartozónak érezheti magát.

Amennyiben az integrációs modell három szintjét az integráció folyamatában gondolom végig, akkor a veszélyeztetett NEET csoport egyes tagjaira a következő fázisok lehetnek jellemzőek, melyek nagymértékben határozzák meg integráltságát: A szocializációjukból eredő együttmüködési képesség, valamint a bizalom és a részvétel szándéka - a már integrálódott közösséghez határozza meg társadalmi integrációjuk mértékét. Ehhez párosul személyközi kapcsolataik, valamint azok minősége és mennyisége; tulajdonképpen az, hogy kikkel és milyen mértékben tartja a NEET-es fiatal a kapcsolatot. E kettőt fogná össze a független rendszerek összehangolt müködése, és tenné a szubjektumot, vagyis a NEET-es fiatalt a rendszer integrált „elemévé”.

Bár alapvetően egyet értek az integrációs modell meghatározásával, annak különböző szintjeivel és mechanizmusaival, ugyanakkor úgy látom, a modell a már integráltnak tekinthető társadalom felől nézi az integrációs folyamat effektív lépéseit, s ezzel szem elől tévesztheti az integrálni kívánt szubjektum szándékát, s annak eleve adott lehetőségeit, melyek éppen a dezintegráltságát fokozzák. 


\section{Módszertan}

Munkámban, mint arra már utaltam, KovÁcH et al. (2016) A magyar társadalom integrációs és rétegződésmodelljei című, a Szociológiai Szemlében megjelent tanulmányát használom fel elsősorban, és az abban megjelent kutatási eredményeket alkalmazom a NEET csoportra.

A tanulmány az integrációs modell három szintjét különbözteti meg: a rendszerintegrációt, a társadalmi szintű integrációt, valamint a személyközi integrációt.

Rendszerintegráció alatt azokat a mechanizmusokat érti, amelyek a szubjektumtól független rendszerek működésének következményeképpen összehangolják a társadalom egyes tagjainak ismétlődő cselekvéseit, és ezáltal megszabják a társadalmi újratermelés kereteit.

Társadalmi szintű integrációs mechanizmusokon a szerzők a kulturális újratermelés, a szocializáció és az együttműködés, a bizalom és részvétel, a közösséghez tartozás kifejezésének folyamatait értik.

A személyközi integráció pedig a közvetlen személyes kapcsolatokat jelenti, amelyek erőforrások lehetnek a rendszerintegrációs folyamatokban történő részvételhez. (KovÁcH et al. 2016.)

A KovÁCH et al. (2016) által létrehozott integrációs modell hét kategóriát tartalmaz, s ezeket alkalmazza a különböző rétegződés modellekben megjelenő csoportokra, illetve osztályokra. Ez a hét kategória a következő: Kapcsolatgazdag politikailag aktívak. Lokálisan integráltak. Munkaerőpiacon integráltak. Rendszerintegráltak. Gyengén integráltak. Normakövető dezintegráltak. Dezintegrált kirekesztettek.

Ezeket a kategóriákat veti össze a munkajelleg-csoportokkal, a státuszcsoportokkal, valamint a látens osztályokkal.

Dolgozatomban az integrációs modell hét kategóriája közül csak azokat használom fel, amelyek külföldi, hazai és saját kutatásaimra is támaszkodva, jellemzik, illetve jellemezhetik a veszélyeztetett NEET csoportot. Ezek a következők: rendszerintegráltak, gyengén integráltak, normakövető dezintegráltak, valamint dezintegrált kirekesztettek. A többi kategória vagy azért nem került bele a vizsgálatomba, mert a NEET fogalma elve kizárta ezt, vagy azért mert az eddigi kutatásokra támaszkodva a NEET csoport tagjai jellemzően nem fordulnak elő ezekben a kategóriákban. Ugyanakkor azt is fontosnak tartom megállapítani, hogy az általam vizsgált csoportok az egyes rétegződési modellekben nem egyértelmúen feleltethetők meg a NEET csoporttal, csupán vagy nagyobb számban fordulnak elő benne, vagy rokoníthatók velük, vagy átfedések mindenképpen megállapíthatók. Így az általam kapott eredmények inkább elméleti megalapozottságúak, melyeknek igazolására további empirikus kutatásokat szükséges folytatni a NEET csoporton belül.

Az integrációs modell általam használt kategóriáiba tartozókat a tanulmány részletesen jellemzi, melyek közül hármat emeltem ki. Az intézménybe vetett bizalom, a szubjektív kirekesztettségérzet és a bizalmas kapcsolatok száma, valamint ezek értékei, melyek lehetnek: magas, átlagos (átlag alatt, vagy átlag felett) és alacsony.

Munkámban, az egyes csoportok vizsgálatánál, egy-egy összefoglaló táblázatot készítettem, melynek jobb oldalán az egyes, általam használt, az integrációs modellben szereplő és azt a csoportot vagy osztályt leginkább jellemző kategóriák vannak. Csak azokat a kategóriákat alkalmaztam (a már fentebb említett négyet), amelyekben a vizsgált csoport vagy osztály a legmagasabb 
százalékos arányokat érte el. Ezt minden egyes kategóriánál zárójelben fel is tűntettem. A táblázat felső részében az általam kiemelt három kategóriajellemző foglal helyet. A táblázatban pedig az egyes kategóriák és azok jellemzőjének értékei állnak.

Ez az összefoglaló táblázat, úgy vélem, szemléletesen mutatja be az egyes csoportok, illetve osztályok integráltsági vagy dezintegráltsági fokát, amelyek leginkább kapcsolatba hozhatók a NEET csoporttal.

Végül a NEET csoportra leginkább jellemző, az integrációs modellben szereplő kategóriákat és az egyes kategóriákra jellemzőket, valamint azok értékeit ábrázolom egy táblázatban. Ez biztosít lehetőséget arra, hogy az integrációs modell segítségével további alcsoportokba rendezhessem a NEET csoportot, melyek egyben kijelölik az integrációs folyamatok lehetséges útjait.

\section{NEET-ES FIATALOK A KÜLÖNBÖZÖ MODELLEKBEN}

Ebben az egységben sorra veszem a korábban már említett társadalmi rétegződésmodelleket, valamint az integrációs modellt, és az eddigi kutatási eredményeimre támaszkodva az egyes modellekben elhelyezem a NEET-es fiatalokat az eddig ismert jellegzetességeik alapján.

Mielőtt rátérek az egyes modellek elemzésére, szeretném ismét kiemelni, hogy a korábban már említett kategóriák közül csak a veszélyeztetett NEET kategóriára koncentrálok. A kevésbé vagy talán egyáltalán nem veszélyeztetett NEET-es fiatalok is elhelyezhetőek a különböző modellekben, de, úgy vélem, őket sokkal inkább integrált csoportnak tekinthetjük, és rájuk nézve nem is kifejezetten szerencsés használni a NEET jelzőt.

\section{NEET és a munkajelleg-csoportok}

Ferge Zsuzsa nevéhez füződő munkajelleg-csoportok (1969) kialakításában hat dimenzió alapján különböztetett meg hét munkajelleg-csoportot. Ezeket a csoportokat megkülönbözteti funkcionálisan, vagyis a különböző foglalkozások tagolódása szerint. Másrészt megkülönbözteti azok társadalmi oldalát, vagyis a foglalkozások egymás közötti kapcsolatát.

ANDORKA Rudolf később (1994) módosította, illetve kiegészítette a Ferge nevéhez köthető eredeti munkajelleg-csoportosítást, és további csoportokat emelt be, illetve különített el egymástól.

KovÁcH et al. (2016) a Ferge-féle és az Andorka-féle munkajelleg-csoportosítások sémáját követve létrehozták saját munkajelleg-csoportjaikat felhasználva a 2008-as Foglalkozások Egységes Osztályozási Rendszerét. Négy nagyobb kategóriát azonosítottak: szellemi foglalkozásúak; fizikai foglalkozásúak; mezőgazdasági foglalkozásúak; egyéb.

A NEET csoportot illetően tulajdonképpen irreleváns lenne elhelyezni azt a munkajellegcsoportok kategóriái között, hiszen a NEET fogalma elve kizárja tagjait a fenti csoportkategóriák szinte mindegyikéből. A kutatók azonban az egyéb kategórián belül létrehoztak egy alcsoportot, amely a „,nem foglalkoztatottak, akik sohasem dolgoztak” nevet viseli. Ebbe az alcsoportba a NEET, úgy vélem, mindenképpen beletartozhat.

Ugyanakkor azt több szakirodalom is megjegyzi, hogy a NEET-es fiatalok mindennapi életükhöz szükséges anyagi fedezetet előteremtik, többnyire a szürke vagy fekete gazdaságból. (SPIELHOFER et al. 2009.; SISSON - JONES 2012.; DWYER - SHAW 2013.; SLOMAN 2014.) Vagyis, feltételezhetően többségük, NEET jellegük ellenére is, dolgozik, csak éppen nem bejelentett munkát vállal. 
Ha ebből az aspektusából vizsgálom a NEET csoportot és vetem össze a kialakított munkajellegcsoportokkal, akkor további két kategóriában is elhelyezhetőek a NEET-es fiatalok, azzal a megkötéssel, hogy ezek a nem legális jellegü munkára vonatkoznak, és erős feltételezésen alapulnak. Ez a két kategória a „,segédmunkások”, és a „,mezőgazdasági fizikai munkások”. Eddigi kutatásaim azt a feltételezésemet támasztják alá, hogy a NEET-es fiatalok egyes csoportjai a napi megélhetésükhöz szükséges anyagi bevételeket elöteremthetik építkezéseken vállalt alkalmi segédmunkából, vagy idénymunkásként mezőgazdasági jellegű napszámból.

KovÁcH et al. (2016) tanulmánya a fent említett három kategóriának a jellemzőit is megadja. A jellemzők szoros rokonságot mutatnak az általam kutatott NEET csoport jellemzőivel, ezek közül is kiemelkedik ,, a nem foglalkoztatottak, sohasem dolgozók kategóriája”. Jellemzésük a következő: Tagjaik karakteres szociológiai tulajdonságokkal írhatók le. A második legfiatalabb csoport, akiknek az iskolai végzettsége kifejezetten alacsony. A nők erősen felülreprezentáltak. A csoport nagy százalékára jellemző a roma származás. S a csoport anyagi helyzete ,drámai jelzővel irható le”. (KovÁcH et al., 2016; p. 14) A fenti felsorolás nagymértékű hasonlóságokat mutat mind a nemzetközi, mind a hazai, mind pedig a saját kutatási eredményeimmel a NEET csoport jellemzőit illetően. (SPIElHOFER et. al. 2009.; COLES et al. 2010.; EurOFOUND 2016.; SÁNTA 2016b)

A másik két kategória, a „segédmunkások” és a „,mezőgazdasági fizikai munkások” kategóriái is mutatnak hasonlóságokat a NEET csoport jellemzőivel, azzal a megkötéssel, hogy a társítás alapvetően feltételezésen nyugszik. A két csoport jellemzője, hogy a községekben állandó lakhellyel rendelkezők felülreprezentáltak. Az iskolai végzettségük alacsony, közöttük öröklött hátrányok mutathatók ki. Továbbá mérhetô a roma származás aránya. Eddigi kutatásaim azt mutatják, hogy a NEET csoport aránya magasabb a kisebb településeken, falvakban, mint a nagyvárosokban. Iskolai végzettségük általában alacsony, s komoly szocializációs hátrányokkal küzdenek. (SÁNTA 2016b; Lásd még: JANCSÁK 2013.)

A munkajelleg-csoportokat tekintve ebben a rendszerben már csak a ,,nem foglalkoztatottak, akik sohasem dolgoztak" kategóriáját vizsgálom az integrációs modell tekintetében, hiszen ez mutat bizonyítható rokonságot a NEET-es fiatalok közösségével. Fontos megjegyezni, hogy ebben a kategóriában az elemszám alacsony $(\mathrm{N}=43)$, és a tanulmány kiemeli, hogy az adatok csak tájékoztató jelegüek.

A vizsgált csoportban a legmagasabb értékeket a rendszerintegráltak, a normakövető dezintegráltak, valamint a dezintegrált kirekesztettek kaptak (86\%).

A rendszerintegráltak bizalmas kapcsolataik száma átlag alatti, mint ahogyan szubjektív kirekesztettség-érzetük is. Az intézményekbe vetett bizalom viszont ebben a csoportban a legmagasabb.

A normakövető dezintegráltak százalékos aránya a legmagasabb (40\%) a csoporton belül. Szubjektív kirekesztettség-érzésük magas, az intézményekbe vetett bizalom viszont a legalacsonyabb. Bizalmas kapcsolataik száma átlag alatti.

S végül a ,,dezintegrált kirekesztettek” jellemzői, hogy bizalmas kapcsolataik száma a legalacsonyabb, a szubjektív kirekesztettség-érzésük igen magas. Ugyanakkor az intézményekbe vetett bizalmuk elmarad az átlagostól.

Mint arra a módszertani részben már utaltam, a tanulmány az integráció három szintjét különbözteti meg: rendszerintegráció, társadalmi szintü integráció, valamint személyközi integráció. Továbbá az integrációs modellben megjelenő egyes kategóriák jellemzői is részletesen olvasható. 
Ezek közül csak azokat a kategóriákat emelem ki, ahol a vizsgált csoport a legnagyobb százalékban képviseltette magát. Ez a munkajelleg-csoportoknál a rendszerintegrált, a normakövető dezintegrált és a dezintegrált kirekesztettek kategóriái. A kategóriák jellemzéséből kiemeltem az intézménybe vetett bizalom, a szubjektív kirekesztettség-érzés, valamint a bizalmas kapcsolatok számára vonatkozó értékeket. Véleményem szerint, e három is elegendő ahhoz, hogy mutassa az adott csoport dezintegráltsági fokát, és egyben jól szemléltetheti a NEET-es fiatalok dezintegráltsági fokát, amelyet minden esetben összehasonlítok az egyes modellekben kiválasztott csoportokkal.

Az első táblázat ezt mutatja be a munkajelleg-csoportokon belül kiválasztott ,,nem foglalkoztatottak, akik sohasem dolgoztak" csoportra vonatkoztatva.

\begin{tabular}{|l|l|l|l|}
\hline & $\begin{array}{c}\text { Intézménybe } \\
\text { vetett bizalom }\end{array}$ & $\begin{array}{c}\text { Szubjektív } \\
\text { kirekesztettség-érzet }\end{array}$ & $\begin{array}{c}\text { Bizalmas } \\
\text { kapcsolatok száma }\end{array}$ \\
\hline Rendszerintegráltak (23\%) & magas & átlag alatt & átlag alatt \\
\hline Normakövető dezintegráltak (40\%) & alacsony & magas & átlag alatt \\
\hline Dezintegrált kirekesztettek (23\%) & átlag alatt & magas & alacsony \\
\hline
\end{tabular}

1. TÁBLÁZAT $A$,,nem foglalkoztatottak, akik sohasem dolgoztak” csoport integrációs jellemzöi az integrációs modellből kiválasztott legjellemzőbb kategóriák és azok jellemzői alapján (Forrás: KovÁcH et. al. (2016), saját szerkesztés)

A táblázatból látható, hogy a „,nem foglalkoztatottak, akik sohasem dolgoztak” csoportja a munkajelleg-csoportokon belül az integrációs modellben egy olyan csoport, amely egy jellemzőben bizonyosan azonos az integráltsági szintjüktől függetlenül: bizalmas kapcsolataik száma alacsony. A másik két jellemzőben azonban úgy tűnik az integrációs modell nem ad egyértelmű képet. Ha a rendszerintegráltság felől nézem a csoportot, akkor az intézménybe vetett bizalmuk magas, de a szubjektív kirekesztettség-érzetük alacsony. Viszont, ha a másik két kategória felől vizsgálom a csoportot, akkor az intézménybe vetett bizalom alacsony, de szubjektív kirekesztettségérzetük magas. Ugyanakkor az kétségtelen, hogy a csoportban a normakövető dezintegráltak vannak jelen a legnagyobb százalékban (40\%), és fontos visszautalni arra, hogy a tanulmány kiemeli az elemszám alacsony voltát és az adatok tájékoztató jellegét.

Amennyiben a NEET csoportra vonatkoztatom ezeket a kategóriákat és jellemzőket, akkor az intézménybe vetett bizalom felől tudok bizonyosabbat állítani a csoportról. Mivel a NEET csoporton belül a helyi foglalkoztatási szerveknél a regisztrációs hajlandóság kifejezetten alacsony (EUROFOUND 2016; ; Lásd még: SÁNTA 2016b), valamint az eddigi tapasztalataim szerint az egyéb szociális szervekkel való együttműködés sem kielégítő, éppen ezért magas a látencia, így nem állítható, hogy többségük rendszerintegrált lenne. Valószínűsíthető, ha a munkajelleg-csoportok és a kiválasztott csoport felől nézem őket, akkor inkább a normakövető dezintegráltak lehetnek nagyobb számban. Bizalmas kapcsolataik száma, úgy tűnik, eddigi kutatásaimra támaszkodva, alacsony, de ez mintha átlagosan jellemző lenne a fiatalokra. (SzÉKELY 2013.) A szubjektív kirekesztettség-érzetükről egyelőre nem tudok konkrét eredményeket prezentálni. Eddigi tapasztalataim nem azt mutatják, hogy kirekesztettnek érezné magát ez a csoport, sokkal inkább azt, hogy nem is tudja mit jelent kirekesztettnek lenni. Ezt további kvalitatív jellegü kutatásokkal lehetne megfelelően bizonyítani, azonban legjobb tudomásom szerint ilyen kutatás a magyarországi NEET csoport körében még nem volt. Kutatásaim azt mutatják, hogy a csoport tagjai, használván az eddig kapott (szükös) szocializációs eszközeiket, , laviroznak”, keresik, ́́gy vagy úgy, a megélhetésüket, a kirekesztettség tudata nélkül. 


\section{NEET és a státuszcsoportok}

A státuszcsoport vizsgálatban a tanulmány szerzői a Kolosi-féle modell (Kolosi 1987., 2000.) logikáját követték. Azonban az eredeti 10 státuszcsoporthoz képes a kutatók nyolc csoportot azonosítottak: Felsőközép. Jól kereső szellemi. Jól kereső szakmunkás, kisvállalkozó. Alsó-közép. Jó lakású alsó. Alacsony beosztású alkalmazott. Vidéki lecsúszottak. Depriváltak. (KovÁCH et al. 2016. 17.)

A NEET csoport, a fogalomból kiindulva itt sem alkalmazható egyértelmű összehasonlításban a státuszcsoportokkal, de átfedéseket és a legnagyobb rokonságot a fenti felsorolásból a két utolsó mutathatja velük.

A ,vidéki lecsúszottak” csoportjára jellemző a magas munkanélküliségi ráta, a vidéki lét és a szakképzetlenség, ugyanakkor magas ebben a csoportban a nyugdíjasok száma.

A ,depriváltak” rétegére az a jellemző, hogy zömmel vidéki városokban és községekben élnek, ellentétben a vidéki lecsúszottakkal, relatíve fiatal csoportról van szó, melyben a legmagasabb a munkanélküliek aránya és a roma származás. Végzettségük alacsony, s a többi csoporthoz képest magas az alkalmi és a közmunkát végzők aránya. Talán ez a csoport mutathat a státuszcsoportok között a legnagyobb átfedést a NEET csoporttal. Erre utalhat fiatal koruk, magas munkanélküliségük, és a közmunkát végzők magas aránya, mint gyakran az egyetlen lehetséges menekülés a munkanélküliségből, főleg vidéken.

Követve a munkajelleg-csoportoknál már használt logikát, a státuszcsoportok esetében ennek a két csoportnak a helyzetét vizsgálom meg az integrációs modellben betöltött kategóriáik és jellemzőjük alapján. Mindkét csoportnál a három legjellemzőbb adatot emeltem ki, és hasonlóan az előzőhöz, táblázatos formában mutatom be.

\begin{tabular}{|l|l|l|l|}
\hline & $\begin{array}{c}\text { Intézménybe } \\
\text { vetett bizalom }\end{array}$ & $\begin{array}{c}\text { Szubjektív } \\
\text { kirekesztettség-érzet }\end{array}$ & $\begin{array}{c}\text { Bizalmas } \\
\text { kapcsolatok száma }\end{array}$ \\
\hline Rendszerintegráltak (22\%) & magas & átlag alatt & átlag alatt \\
\hline Gyengén integráltak (20\%) & átlagos & átlag felett & átlag felett \\
\hline Normakövető dezintegráltak (24\%) & alacsony & magas & átlag alatt \\
\hline
\end{tabular}

2. TÁBLÁzAT $A$,, vidéki lecsúszottak” státuszcsoport integrációs jellemzői az integrációs modellből kiválasztott legjellemzőbb kategóriák és azok jellemzői alapján (Forrás: KovÁcH et. al. (2016), saját szerkesztés)

A ,vidéki lecsúszottak” státusza az integrációs modellben a legnagyobb százalékos arányokat a rendszerintegráltak, a gyengén integráltak és a normakövető dezintegráltak kategóriáiban érték el (66\%).

Az adatokat összevetve erről a csoportról nehéz az integrációs modell alapján eldönteni, hogy mennyi a bizalmas kapcsolataik száma (átlag körüli értéket mutat), vagyis hogy a személyközi kapcsolataikban integráltak-e, vagy sem. Mint ahogyan kifejezetten ellentmondásos a rájuk jellemző szubjektív kirekesztettség-érzet és az intézménybe vetett bizalom mértéke is. Ez talán visszavezethető arra, hogy ebben a csoportban magas a nyugdíjasok száma, akiknek bizalmas kapcsolataik feltételezhetően csökkenőben vannak, de még jellemezheti őket az intézményekbe vetett bizalom. 
A NEET csoportra vonatkoztatva ezeket a kategóriákat és jellemzőket, hasonlókat lehet megállapítani, mint a munkajelleg-csoportoknál, csak itt még bizonytalanabbul, mint ahogyan ott tehettem. Ennek egyik oka talán a már említett nyugdíjasok jelentős száma, bár az elgondolkodtató lehet, hogy ezekkel a jellemzőkkel bíró szülők vagy nagyszülők, milyen szocializációs stratégiákat adnak tovább gyerekeiknek, unokáiknak. A kutatások azt mutatják, hogy a fiatalokat bár ma már a „,digitális bennszülött” jelzővel illethetjük, de a szülőktől kapott hagyományokat, stratégiákat továbbviszik. (SÁGVÁRI 2013.; SzÉKELY 2013.)

A harmadik táblázat a státuszcsoportokon belül a másik kiválasztott csoportot a ,,depriváltak” csoportját mutatja be, a már korábban ismertetett jellemzőkkel.

\begin{tabular}{|l|l|l|l|}
\hline & $\begin{array}{c}\text { Intézménybe } \\
\text { vetett bizalom }\end{array}$ & $\begin{array}{c}\text { Szubjektív } \\
\text { kirekesztettség-érzet }\end{array}$ & $\begin{array}{c}\text { Bizalmas } \\
\text { kapcsolatok száma }\end{array}$ \\
\hline Gyengén integráltak (20\%) & átlagos & átlag felett & átlag felett \\
\hline Normakövető dezintegráltak (20\%) & alacsony & magas & átlag alatt \\
\hline Dezintegrált kirekesztettek (23\%) & átlag alatt & magas & alacsony \\
\hline
\end{tabular}

3. TÁBLÁZAT $A$,,depriváltak” státuszcsoport integrációs jellemzői az integrációs modellböl kiválasztott legjellemzöbb kategóriák és azok jellemzői alapján

(Forrás: KovÁcH et. al. (2016), saját szerkesztés)

A ,,depriváltak” státusza, mint ahogyan utaltam már rá, a státuszcsoportok között a legnagyobb átfedést és rokonságot mutathatja a NEET csoporttal. Ez a csoport a gyengén integráltak, a normakövető dezintegráltak és a dezintegrált kirekesztettek kategóriáiban mutatta a legmagasabb százalékos arányokat (66\%).

Ez a státusz a leginkább homogén az integrációs modell egyes csoportjaiban kiemelt három jellemzőkben. Az intézménybe vetett bizalmuk átlagos, de inkább átlag alatti. A szubjektív kirekesztettség-érzetük magasnak tekinthető. Míg a bizalmas kapcsolataik száma inkább az átlag körüli. Vagyis az ebbe a státuszba tartozó emberek többsége nem igazán bízik az intézményekben, kapcsolataik száma átlagos, de kifejezetten kirekesztettnek érezhetik magukat.

Eddigi kutatásaim a NEET témán belül azt mutatják, hogy ez a státusz, a ,depriváltak” státusza mutathatja a legközelebbi rokonságot a veszélyeztetett NEET-es fiatalok csoportjával.

\section{NEET és a BBC-modell}

A BBC modell, mint társadalmi rétegződés-modell (SAVAGE et al. 2013.) a Bourdieu-féle tőkefajták (gazdasági, kulturális, társadalmi) birtoklásának mértéke alapján hozta létre a társadalmi csoportokat. (KovÁCH et al. 2016.)

A modell magyar adaptációja (KovÁcH et al. 2016.) nyolc látens társadalmi osztályt hozott létre a magyar társadalomban a felső osztálytól a prekariátus osztályig bezárólag.

Az integrációs modell az eredeti BBC modellt és annak magyar adaptációját követve nyolcosztályos osztálystruktúrát hozott létre (KovÁcH et al. 2016.), melyből, a témámat tekintve, két osztály mutathat rokonságot, illetve lehetnek átfedések a veszélyeztetett NEET-es fiatalokkal: a , leszakadók, depriváltak”, és a „,mélyszegények” osztályai. 
A , leszakadók, depriváltakra” jellemző, hogy a munkaerő-piaci aktivitásuk elmarad a többi csoportétól, a munkanélküliségi ráta magas. Iskolai végzettségük alacsony, jelentős százalékuk (40\%) a legalacsonyabb iskolai végzettséggel rendelkezik. Többnyire vidéki, illetve falusias csoport, melyben a romák aránya átlag feletti. Ugyanakkor az átlag életkoruk a második legmagasabb a látens osztályokon belül (58 év), amely azt mutatja, hogy a NEET-es fiatalok, e modellstruktúrájában, talán kevesebb számban vannak jelen.

A következő táblázat a fentiekhez hasonlóan, azt mutatja be, hogy százalékos arányban, mely kategóriákban jelentek meg a , leszakadók, depriváltak” osztálya az integrációs modell szerint. Továbbá, hogy milyen jellemzőik voltak a különböző területeken.

\begin{tabular}{|l|l|l|l|}
\hline & $\begin{array}{c}\text { Intézménybe } \\
\text { vetett bizalom }\end{array}$ & $\begin{array}{c}\text { Szubjektív } \\
\text { kirekesztettség-érzet }\end{array}$ & $\begin{array}{c}\text { Bizalmas } \\
\text { kapcsolatok száma }\end{array}$ \\
\hline Rendszerintegráltak (24\%) & magas & átlag alatt & átlag alatt \\
\hline Gyengén integráltak (21\%) & átlagos & átlag felett & átlag felett \\
\hline Normakövető dezintegráltak (20\%) & alacsony & magas & átlag alatt \\
\hline
\end{tabular}

4. TÁBLÁZAT $A$,, leszakadók, depriváltak” osztály integrációs jellemzői az integrációs modellből kiválasztott legjellemzőbb kategóriák és azok jellemzői alapján

(Forrás: KovÁcH et. al. (2016), saját szerkesztés)

A ,,leszakadók, depriváltak” osztályán belül, a kutatás szerint, a legmagasabb arányban a rendszerintegráltak, a gyengén integráltak és a normakövető dezintegráltak jelentek meg (65\%).

A bizalmas kapcsolatok száma tekintetében elmondható, hogy a , leszakadók, depriváltak”, az integrációs modell szerint, átlagos kapcsolati hálóval rendelkeznek. Többségüknek a szubjektív kirekesztettség-érzetük átlagos, de inkább a magas felé tendál. Viszont az intézménybe vetett bizalmuk eltérő, ingadozó. Vannak közöttük, akiknek magas, de jelentősebb számban átlagos, vagy alacsony bizalommal vannak a különböző intézmények felé.

Vagyis ennek csoportnak jelentős része, a kutatás szerint, rendelkezik kapcsolatokkal, inkább kirekesztettnek érzi magát, de feltehetően kevesebben fordulnak intézményi segítségért. Ennek egyik feltételezhető oka, hogy az átlag életkor kifejezetten magas ebben a csoportban.

A NEET-es fiatalokra vonatkoztatva ezt az osztályt, megállapítható, hogy a BBC modell osztálykategóriái szerint ebben a csoportban talán kevesebb NEET-es fiatal található összességében. Amennyiben azonban előfordulnak, akkor elképzelhetően a szüleik, családtagjaik hozzáállását viszik tovább; tehát lehetnek ugyan kapcsolataik, de nem fordulnak jelentősebb számban intézményi segítségért. Ez talán magyarázat lehet arra, hogy miért annyira alacsony a regisztrált NEET-es fiatalok száma a helyi foglalkoztatási szerveknél. (EUROFOUND 2016.; SÁNTA 2016b)

A ,,mélyszegények”, KovÁcH et al. (2016) kutatása szerint, gyakorlatilag szinte semmilyen tőkével sem rendelkező csoport. Kifejezetten alacsony az aktivitásuk a munkaerő-piacon, a munkanélküliség viszont magas. Képzetlenek, 59\%-uk mindössze alapfokú végzettséggel rendelkezik. Átlagéletkorukat tekintve a legidősebb csoport (59 év), és közöttük a legmagasabb a romák aránya. Jelentős részük nyugdíjas, s mindezeket figyelembe véve, hasonló mondható el, mint az előző osztályról: feltehetőleg a NEET-es fiatalok aránya alacsony ebben az osztályban is, de mindenképpen jelen lehetnek. 
Az ötödik táblázat a „,mélyszegények” BBC modell szerinti osztályát mutatja be, elhelyezve azt az integrációs modell kategóriáiban és jellemzőiben.

\begin{tabular}{|l|l|l|l|}
\hline & $\begin{array}{c}\text { Intézménybe } \\
\text { vetett bizalom }\end{array}$ & $\begin{array}{c}\text { Szubjektív } \\
\text { kirekesztettség-érzet }\end{array}$ & $\begin{array}{c}\text { Bizalmas } \\
\text { kapcsolatok száma }\end{array}$ \\
\hline Rendszerintegráltak (24\%) & magas & átlag alatt & átlag alatt \\
\hline Normakövető dezintegráltak (36\%) & alacsony & magas & átlag alatt \\
\hline Dezintegrált kirekesztettek (18\%) & átlag alatt & magas & alacsony \\
\hline
\end{tabular}

5. TÁBLÁZAT $A$,,mélyszegények” osztálya integrációs jellemzői az integrációs modellből kiválasztott legjellemzőbb kategóriák és azok jellemzői alapján

(Forrás: KovÁcH et. al. (2016), saját szerkesztés)

A ,,mélyszegények” három kategóriában mutatták a legmagasabb arányokat (78\%); rendszerintegráltak, dezintegrált kirekesztettek, és kifejezetten magas az arányuk a kutatás szerint, a normakövető dezintegráltaknak (36\%).

A bizalmas kapcsolataik számát tekintve átlag alatti, de inkább alacsony. Szubjektív kirekesztettségérzetük kifejezetten magas, de a csoporton belül a rendszerintegráltak között inkább átlag alatti. Ez utalhat arra, hogy a „,mélyszegények” osztályán belül azoknak, akik kapcsolatot tartanak fent valamely szolgáltató intézménnyel, és ebből kifolyólag támogatásokban részesülhetnek, alacsonyabb a szubjektív kirekesztettség-érzetük, mint a csoport többi tagjának. Az intézménybe vetett bizalom szempontjából elmondható, hogy az inkább alacsony, a csoport jelentős többsége nem bízik a különböző intézményekben (54\%). Azok fordulnak feléjük, akik a modell szerint rendszerintegráltak.

A NEET-es fiatalokra vonatkoztatva ezt az osztályt, hasonló megállapítások tehetők, mint az előző osztálynál. Vagyis feltételezhető, hogy a BBC modell osztálykategóriái szerint ebben a csoportban kevesebb NEET-es fiatal található összességében. Amennyiben azonban előfordulnak, akkor elképzelhetően a szüleik, családtagjaik hozzáállását viszik tovább. Viszont a kapcsolataik száma kifejezetten alacsony, sőt jelentős részük elfordul, vagy már elfordult az intézményi segítségtől. A Eurofound kutatásában (2016) elképzelhetően ők azonosíthatóak azokkal a NEET-es fiatalokkal, akik azért nem fordulnak az intézmények felé, mert már nem is hisznek abban, hogy találnak lehetőségeket.

\section{NEET ÉS AZ INTEGRÁCIÓS MODELL}

Végül, ebben az egységben, az integrációs modellen keresztül eddig levont következtetéseimet vonatkoztatom a NEET-es fiatalok csoportjára.

KovÁcH et al. (2016) tanulmányát alapul véve, és kutatási eredményeikre támaszkodva megvizsgáltam, hogy az egyes társadalmi rétegződésmodellekben, melyik kategóriákkal lehetne azonosítani, rokonítani, vagy legalább átfedéseket találni a NEET-es fiatalokkal. Vizsgálatomba a munkajelleg-csoportokat, a státuszcsoportokat, és a látens osztálymodellt vontam be, de úgy, hogy ehhez felhasználtam az integrációs modell kategóriáit és jellemzőit. 
Egyrészt megnéztem, hogy az egyes modelleken belül, mely munkajelleg-csoporttal, mely státuszcsoportokkal és mely látens osztályokkal mutat(hat)nak hasonlóságot a NEET csoportra jellemzőek. Majd ezek közül kiválasztottam azokat az integrációs modellben meghatározott kategóriákat, melyekben a kutatás szerint a legmagasabb százalékos arányokat mutatta/mutatták a csoport(ok); tehát a legmarkánsabban ezekben a kategóriákban képviseltették magukat az egyes csoportok tagjai. Az egyes kategóriák jellemzői közül, melyeket az integrációs modell állapított meg, kiválasztottam hármat: intézménybe vetett bizalom, szubjektív kirekesztettség-érzet és bizalmas kapcsolatok száma. E három jellemző, úgy vélem, megfeleltethető az integrációs modell három szintjének, és egyben mutathatják a NEET-es fiatalok jellemzőit is. Ezt követően készítettem egy táblázatot, melyben az egyes csoportok integrációs modell szerinti azon kategóriái vannak feltűntetve, melyekben az adott csoport a legmagasabb százalékos arányokat mutatta, illetve a táblázat tartalmazza a három általam kiválasztott jellemzőket és ezek értékeit. Végül ezeket az értékeket és jellemzőket vonatkoztattam a NEET csoportra.

Ebben az egységben, az eddigi tapasztalataimat felhasználva, már csak az integrációs modellt, illetve az általa levonható következtetéseimet összegzem az egyes rétegződési modellekben azonosított csoportokkal, melyek a leginkább kapcsolhatók a NEET csoporthoz.

Ezek a következők voltak: A munkajelleg-csoportokon belül a „,nem foglalkoztatottak, akik sohasem dolgoztak". Az integrációs modell szerint rájuk leginkább jellemző, hogy rendszerintegráltak, normakövető dezintegráltak és dezintegrált kirekesztettek (86\%) a csoporton belül, bár itt az elemszám kifejezetten alacsony volt, ezért az adatok csak tájékoztató jellegűek.

A státuszcsoportokon belül a „,vidéki lecsúszottak” és a „depriváltak”. Öket leginkább a rendszerintegráltság, a gyengén integráltság és a normakövető dezintegráltság (66\%), valamint a gyengén integráltság, a normakövető dezintegráltság és a dezintegrált kirekesztettség (63\%) jellemezte a csoportjukon belül.

Végül a BBC modellben szintén két osztály volt kiválasztható, a ,,leszakadók, depriváltak” és a „mélyszegények”. Jellemzőjük, hogy rendszerintegráltak, gyengén integráltak és normakövető dezintegráltak (65\%), valamint rendszerintegráltak, normakövető dezintegráltak és dezintegrált kirekesztettek (78\%) a csoportjukon belül.

A fenti adatokat figyelembe véve, s azt a tényt, hogy ezek a csoportok nem NEET-es csoportok, de nagy valószínüséggel számos NEET-es fiatal lehet közöttük, az integrációs modellt alapul véve a NEET-es fiatalok között a legnagyobb számban előfordulók a:

- rendszerintegráltak,

- gyengén integráltak,

- normakövető dezintegráltak,

- dezintegrált kirekesztettek.

Az eddig használt táblázatot alkalmazva, a következő oldalon található táblázatban látható értékek mutathatóak ki a NEET csoporton belül az integrációs modell kategóriáit és jellemzőit használva.

Azt az előfeltevést a dolgozat elején már megtettem, hogy a veszélyeztetett NEET csoportba tartozó fiatalok dezintegráltak, s ezt számos kutatás is bizonyította. (SPIELHOFER et al. 2009.; COLES et al. 2010.; Sission - JONES 2012; EUROFOUND 2016.; SÁNTA 2016b)

Az integrációs modellt használva úgy tünik, hogy a dezintegrált NEET csoporton belül a fiatalok egyes tagjai leginkább rendszerintegráltak, akiknél magas az intézménybe vetett bizalom, 


\begin{tabular}{|l|l|l|l|}
\hline & $\begin{array}{c}\text { Intézménybe } \\
\text { vetett bizalom }\end{array}$ & $\begin{array}{c}\text { Szubjektív } \\
\text { kirekesztettség-érzet }\end{array}$ & $\begin{array}{c}\text { Bizalmas } \\
\text { kapcsolatok száma }\end{array}$ \\
\hline Rendszerintegráltak & magas & átlag alatt & átlag alatt \\
\hline Gyengén integráltak & átlagos & átlag felett & átlag felett \\
\hline Normakövető dezintegráltak & alacsony & magas & átlag alatt \\
\hline Dezintegrált kirekesztettek & átlag alatt & magas & alacsony \\
\hline
\end{tabular}

6. TÁBLÁZAT $A$ veszélyeztetett NEET csoport integrációs modellben meghatározható jellemzői a modellböl kiválasztott legjellemzöbb kategóriák és azok jellemzői alapján

(Forrás: KovÁcH et al. (2016) tanulmányára támaszkodva saját szerkesztés)

de átlag alattinak tekinthető a szubjektív kirekesztettség-érzet és a bizalmas kapcsolatok száma is. Gyengén integráltak, akiknél magas a szubjektív kirekesztettség-érzet, de alacsony az intézménybe vetett bizalom, és átlag alattinak tekinthető a bizalmas kapcsolataik száma is. Továbbá normakövető dezintegráltak, és dezintegrált kirekesztettek, akiknél magas a szubjektív kirekesztettségérzet, de alacsonynak tekinthető mind az intézménybe vetett bizalom, mind pedig a bizalmas kapcsolataik száma.

Ezek a megállapítások, kétségtelen tény, közelebb vihetnek a NEET csoport jobb megértéséhez, de az elméleti eredményeket további empirikus kutatásoknak kell visszaigazolni. Az mindenképpen megállapítható, hogy a veszélyeztetett NEET csoport tagjai dezintegráltak, de az nem mindegy, hogy melyik nézőpontból. Számomra úgy tünik, hogy a rendszer, ha úgy tetszik a társadalom felől nézve dezintegráltak a NEET csoport tagjai. Vagyis azt nem tudjuk (még), hogy ők minek tartják magukat, s egyáltalán tudják-e, hogy dezintegráltak, és hogy lehetnének integráltak is.

Úgy vélem, ha csak és kizárólag a rendszer felől nézzük és határozzuk meg az integrációt és annak folyamatát, akkor az integráció lehet egy erőszakos folyamat, és mint ilyen, célját vesztett, sőt akár kirekesztő is lehet a NEET csoport egyes tagjaira nézve.

Az integráció, mint azt fentebb már említettem, úgy gondolom, egy működő társadalom attribútuma és folyamata kell, hogy legyen, amely mindenképpen magában foglal cselekvési terve(ke)t is, mely által a társadalom újratermelődik és működőképes. Ehhez mindenképen az integráció folyamatának, illetve azoknak, akik ebben részt vesznek, figyelembe kell venniük azt, hogy az integrálni kívánt személy, vagy csoport, legyenek ők akár a NEET-esek, mit akarnak. Ehhez, véleményem szerint, jól felhasználhatók az integrációs modell segítségével tehető strukturális megállapítások a NEET csoportról.

Ha közelebbről szemügyre vesszük az eredményeket, akkor jól látszik, hogy két csoport hozható létre, jellemzőik alapján, a NEET csoporton belül.

Az egyik a rendszerintegrált és gyengén integrált NEET-es fiatalok csoportja. Ök, feltételezhetően, azok közé a fiatalok közé tartoznak, akik a különböző rendszerekkel már valamilyen kapcsolatban vannak. Talán éppen közöttük van az a mintegy 37\%, akik regisztráltak, mint álláskeresők a hivatalos szerveknél. (EUROFOUND 2016.) Vagy, akik egyéb szolgáltató szervekkel állnak kapcsolatban a változás reményében. Az ő integrációjuk alapfeltétele, véleményem szerint, az oktatás 
és képzés, illetve az ezekbe a rendszerekbe való (vissza)integrálás. Ez a folyamat szubjektív kirekesztettség-érzetüket csökkentheti, ugyanakkor növelheti bizalmas kapcsolataik számát.

A másik csoport a normakövető dezintegráltak és a dezintegrált kirekesztettek csoportja. Ők, feltételezhetően, semmilyen rendszernek nem tagjai, sőt inkább elfordulnak azoktól a rendszerektől, melyek tőlük függetlenül, de mégis cselekvésre késztetné őket. Mivel náluk alacsony a bizalmas kapcsolatok száma is, így az integráció első lépéseként egy úgynevezett informatív oktatást javasolnék. Ezt a feladatot leginkább a jól képzett utcai szociális munkások tudnák ellátni, azokon a helyeken, ahol ezek a fiatalok nagyobb számban feltünhetnek. Ezek a szakemberek, az informális oktatáson keresztül (mondhatjuk úgy is, barátkozás, információcsere, bizalomfelkeltés) fontos bizalmi kapcsolatokat építhetnek ki, s egyben információt adhatnak arról a rendszerről is, melyben ezeknek a fiataloknak a bizalmuk megcsappant. A cél, gyakorlatilag, rendszerintegrálttá tenni őket, de azon az úton és olyan sebességgel, amelyet ők választhatnak meg. Ezt követően az integráció folyamata már az első csoportra meghatározott terveket követheti.

\section{ÖSSZEGZÉS}

Munkámban KovÁcH et al. (2016) A magyar társadalom integrációs és rétegződésmodelljei című, a Szociológiai Szemlében megjelent tanulmányát használtam fel elsősorban, és az abban megjelent kutatási eredményeket alkalmaztam a NEET csoportra.

A kutatásban felsorolt rétegződési modellek közül néhánnyal kívántam összevetni a NEET csoport fiataljait, azonosítani helyzetüket ezekben a modellekben, és reflektálni az integrálhatóságukkal kapcsolatban felmerült dilemmáimra.

KovÁcH et al. tanulmánya alapvetően három rétegződés- és egyenlőtlenségmodellre fókuszált: a munkajelleg-csoportokra, státuszcsoportokra, valamint az úgynevezett BBC-modellre, vagy látens osztálymodellre. Végül az integráció/dezintegráció mérésére és jellemzésére szolgáló modellre.

A fent említett első három modellben a NEET csoportot igyekeztem elhelyezni és reflektálni helyzetükre, majd az integrációs/dezintegrációs modellt figyelembe véve vontam le következtetéseimet a NEET csoport integrálhatóságával kapcsolatban.

Munkám első szerkezeti egységében a NEET csoport általánosan elfogadott csoportbontásait használtam, és alapvetően a veszélyeztetett NEET csoportról adtam összefoglalót. Ez kijelölte státuszukat az integrált - dezintegrált tengelyen. Majd pedig az integráció fogalmát jártam körbe szakirodalmak alapján.

Elemzésemből kiderült, hogy a NEET csoporthoz leginkább köthető csoportok, illetve osztályok a következők voltak: A munkajelleg-csoportokon belül a ,,nem foglalkoztatottak, akik sohasem dolgoztak”. Az integrációs modell szerint rájuk leginkább jellemző, hogy rendszerintegráltak, normakövető dezintegráltak és dezintegrált kirekesztettek (86\%) a csoporton belül, bár itt az elemszám kifejezetten alacsony volt, ezért az adatok csak tájékoztató jellegüek.

A státuszcsoportokon belül a ,,vidéki lecsúszottak” és a ,,depriváltak”. Őket leginkább a rendszerintegráltság, a gyengén integráltság és a normakövető dezintegráltság (66\%), valamint a gyengén integráltság, a normakövető dezintegráltság és a dezintegrált kirekesztettség (63\%) jellemezte csoportjukon belül.

Végül a BBC modellben szintén két osztály volt kiválasztható, a ,,leszakadók, depriváltak” és a „,mélyszegények”. Jellemzőjük, hogy rendszerintegráltak, gyengén integráltak és normakövető 
dezintegráltak (65\%), valamint rendszerintegráltak, normakövető dezintegráltak és dezintegrált kirekesztettek (78\%) csoportjukon belül.

Az adatokat figyelembe véve, továbbá azt a tényt, hogy ezek a csoportok nem NEET-es csoportok, de nagy valószínűséggel számos NEET-es fiatal lehet közöttük, az integrációs modellt alapul véve a NEET-es fiatalok között a legnagyobb számban előfordulók: a rendszerintegráltak, a gyengén integráltak, a normakövető dezintegráltak és a dezintegrált kirekesztettek.

Azt az előfeltevést tettem a dolgozat elején, hogy a veszélyeztetett NEET csoportba tartozó fiatalok dezintegráltak, s ezt számos kutatás is bizonyította. Az integrációs modellt használva úgy tűnik, hogy a dezintegrált NEET csoporton belül a fiatalok egyes tagjai leginkább rendszerintegráltak, akiknél magas az intézménybe vetett bizalom, de átlag alattinak tekinthető a szubjektív kirekesztettség-érzet és a bizalmas kapcsolatok száma is. Gyengén integráltak, akiknél magas a szubjektív kirekesztettség-érzet, de alacsony az intézménybe vetett bizalom, és átlag alattinak tekinthető a bizalmas kapcsolataik száma is. Továbbá normakövető dezintegráltak, és dezintegrált kirekesztettek, akiknél magas a szubjektív kirekesztettség-érzet, de alacsonynak tekinthető mind az intézménybe vetett bizalom, mind pedig a bizalmas kapcsolataik száma.

Ezek a vizsgálati eredmények, kétségtelen tény, közelebb vihetnek a NEET csoport jobb megértéséhez, de az elméleti eredményeket további empirikus kutatásoknak kell visszaigazolni. Az mindenképpen megállapítható, hogy a veszélyeztetett NEET csoport tagjai dezintegráltak, de az nem mindegy, hogy melyik nézőpontból. Számomra úgy tünik, hogy a rendszer, ha úgy tetszik a társadalom felől nézve dezintegráltak a NEET csoport tagjai. Vagyis azt nem tudjuk (még), hogy ők minek tartják magukat, s egyáltalán tudják-e, hogy dezintegráltak, és hogy lehetnének integráltak is.

Ha csak és kizárólag a rendszer felől nézzük és határozzuk meg az integrációt és annak folyamatát, akkor az integráció lehet egy erőszakos folyamat, és mint ilyen, célját vesztett, sőt akár kirekesztő is lehet a NEET csoport egyes tagjaira nézve.

Az integráció, úgy gondolom, egy működő társadalom attribútuma és folyamata kell, hogy legyen, amely mindenképpen magában foglal cselekvési terve(ke)t is, mely által a társadalom újratermelődik és működőképes. Ehhez az integráció folyamatának, illetve azoknak, akik ebben részt vesznek, figyelembe kell venniük azt, hogy az integrálni kívánt személy, vagy csoport, legyenek ők akár a NEET-esek, mit akarnak. Ehhez, véleményem szerint, jól felhasználhatók az integrációs modell segítségével tehető strukturális megállapítások a NEET csoportról.

Ha szemügyre vesszük az eredményeket, akkor jól látszik, hogy két csoport hozható létre, jellemzőik alapján, a NEET csoporton belül.

Az egyik a rendszerintegrált és gyengén integrált NEET-es fiatalok csoportja. Ők, feltételezhetően, azok közé a fiatalok közé tartoznak, akik a különböző rendszerekkel már valamilyen kapcsolatban vannak. Talán éppen közöttük van az a mintegy $37 \%$, akik regisztráltak, mint álláskeresők a hivatalos szerveknél. Vagy, akik egyéb szolgáltató szervekkel állnak kapcsolatban a változás reményében. Az ő integrációjuk alapfeltétele, véleményem szerint, az oktatás és képzés, illetve az ezekbe a rendszerekbe való (vissza)integrálás. Ez a folyamat szubjektív kirekesztettségérzetüket csökkentheti, ugyanakkor növelheti bizalmas kapcsolataik számát.

A másik csoport a normakövető dezintegráltak és a dezintegrált kirekesztettek csoportja. Ők, feltételezhetően, semmilyen rendszernek nem tagjai, sőt inkább elfordulnak azoktól 
a rendszerektől, melyek tőlük függetlenül, de mégis cselekvésre késztetné őket. Mivel náluk alacsony a bizalmas kapcsolatok száma is, így az integráció első lépéseként egy úgynevezett informatív oktatást javasolnék. Ezt a feladatot leginkább a jól képzett utcai szociális munkások tudnák ellátni, azokon a helyeken, ahol ezek a fiatalok nagyobb számban feltűnhetnek. Ezek a szakemberek, az informális oktatáson keresztül fontos bizalmi kapcsolatokat építhetnek ki, s egyben információt adhatnak arról a rendszerről is, melyben ezeknek a fiataloknak a bizalmuk megcsappant. A cél, gyakorlatilag, rendszerintegrálttá tenni őket, de azon az úton és olyan sebességgel, amelyet ők választhatnak meg. Ezt követően az integráció folyamata már az első csoportra meghatározott terveket követheti.

KovÁCH et al. (2016) tanulmánya összegzésében fontos megállapításokat tesz. Kutatásuk szerint a dezintegrált csoportok aránya 33-38 százalék közötti a mai magyar társadalomban. A szegények szolidaritása, ezen társadalmi csoport összefogása már a múlté, melyet az individualizáció váltott fel. A NEET csoportra ez kifejezetten jellemző lehet. A tanulmány egyik összegző megállapítása szerint, ,, az egyenlötlenségek kutatásakor elkerülhetetlen az integrációra/ dezintegrációra vonatkozó információk, modellek figyelembevétele és alkalmazása”. (p. 24) Ezzel a megállapítással teljes mértékben egyet lehet érteni, sőt úgy vélem, támogatni szükséges, de azt mindenképpen hozzátenném, hogy az integráció folyamata akkor lehet a legsikeresebb, ha a folyamatban résztvevők szorosan együttmüködnek azokkal, felvilágosítják azokat, kíváncsiak azok véleményére, sőt meghívják azokat, akiket integrálni szeretnének.

\section{IRODALOM}

ANDORKA R. (1994): A rétegződéselmélet haszna a mai magyar társadalom kutatásában. In Andorka R. - Hradil, S. - Peschar, L. J. (szerk.): Társadalmi rétegződés. Budapest, AULA. AudiT COMMISSION (2010): Against the odds. Re-engaging young people in education, employment or training. London, Audit Commission Publishing Team.

Barta N. - Csoba J. - Harmati K. - Hegyi L. (2016): „Útvesztő” Az iskolából lemorzsolódott 15-19 évesek mindennapjai. Metszetek vol. 5. no. 3. 103-120.

Coles, B. - Godfrey, Ch. - Keung, A. - Parott S. - Bradshaw, J. (2010): Estimating the lifetime cost of NEET: 16-18 year olds not in Education, Employment or Training. Department of Social Policy and Social Work and Department of Health Sciences. The University of York.

DUPCSIK Cs. (2012): Az integráció fogalma a társadalomtudományos és a laikus társadalomképekben az oktatási integráció példáján keresztül. In Kovách, I. - Dupcsik, Cs. - P. Tóth, T. - Takács, J. (szerk.) (2012): Társadalmi integráció a jelenkori Magyarországon. Tanulmányok. MTA. Társadalomtudományi Kutatóközpont - Argumentum. 243-261.

Dwyer, P. - Shaw, S. (2013): An Introdiction to Social Policy. London, Sage Publicationa Ltd.

ELDER, S. (2015): What does NEETs mean and why is the concept so easily misinterpreted? International Labour Office. http://www.ilo.org/wcmsp5/groups/public/@dgreports/@dcomm/ documents/publication/wcms_343153.pdf (letöltés dátuma: 2016. december 18.)

Elindult az ifjúsági garancia program. http://www.kormany.hu/hu/nemzetgazdasagi-miniszterium/ munkaeropiaci-es-kepzesi-allamtitkarsag/hirek (letöltés dátuma: 2015. február 20.) 
EUROFOUND (2016): Exploring the diversity of NEETs. Publications Office of the European Union, Luxembourg. http://www.eurofound.europa.eu/publications/report/2016/labour-market-socialpolicies/exploring-the-diversity-of-neets (letöltés dátuma: 2016. december 18.)

FERGE Zs. (1969): Társadalmunk rétegződése. Elvek és tények. Budapest. Közgazdasági és Jogi Könyvkiadó.

FERGE Zs.(1990): Variációk a társadalmi integráció témájára. Esély 2. évf. 1. sz. 3-17.

JANCSÁK CS. (2013): Ifjúsági korosztályok korszakváltásban. Budapest, Új Mandátum Könyvkiadó.

Kolosi T. (1987): Tagolt társadalom. Budapest, Gondolat Kiadó.

Kolosi T. (2000): A terhes babapiskóta. Budapest, Osiris Kiadó.

KovÁch I. - HAJdú G. - GERŐ M. - KRISTÓF L. - SzABÓ A. (2016): A magyar társadalom integrációs és rétegződésmodelljei. Szociológiai Szemle 26. évf. 3. sz. 4-24.

SÁGVÁRI B. (2012): Az átmenetek kora? - A magyar fiatalok társadalomképéről. In Kovách, I. Dupcsik, Cs. - P. Tóth, T. - Takács, J. (szerk.) (2012): Társadalmi integráció a jelenkori Magyarországon. Tanulmányok. MTA. Társadalomtudományi Kutatóközpont-Argumentum. 63-82.

SÁNTA T. (2016b): NEET-Kutatás - Szegedre vonatkozó statisztikai adatok tükrében. In Jancsák Cs. Krémer A. (szerk.): Kisvárosi Fiatalok, Kisebbségek, Új Sebezhetőségek. Európai Ifjúsági Kutató-, Szervezetfejlesztő és Kommunikációs Központ - Belvedere Meridionale. 111-146.

SÁNTA, T. (2016a): Youngsters Who Are Not in Employment, Education or Training (About the NEET in a Hungarian Perspective). Belvedere Meridionale 28. évf. 2. sz. 120-131.

Savage, M. - Devine, F. - Cunningham, N. - Taylor, M. - Li, Y. - Huellbrekke, J. LeRoux, B. - Friedman, S. - Miles, A. (2013): A new model of social class: Findings from the BBC's great british class survey experiment. Sociology vol. 47. no. 2. 219-250.

SisSON, P. - JONES, K. (2012): Lost in transition? The changing labour market and young pople not in employment, education or training. London, The Work Foundation. Part of Lancaster University.

SLOMAN, M. (2014): A Black Paper on NEETs and Apprenticeship. http://www.trainingjournal.com (letöltés dátuma: 2016. november 06.)

Spielhofer, Th. - Benton, T. - Evans, K. - Featherstone, G. - Golden, S. - Nelson, J. SMith, P. (2009): Increasing Participation: Understanding Young People who do not Participate in Education or Training at 16 and 17. Department for Children, Schools and Families. National Foundation for Educational Research. DCSF Publications. Nottingham. http://www.dera.ioe.ac.uk/ 11328/1/DCSF-RR072.pdf (letöltés dátuma: 2015. május30.)

SzÉKELY L. (szerk.) (2013): Magyar Ifjúság 2012. Tanulmánykötet. Budapest, Magyar Közlöny Lap- és Könyvkiadó. 88-125. http://kutatopont.hu/files/2013/09/Magyar_Ifjusag_2012_ tanulmanykotet.pdf (letöltés dátuma: 2016. december 27.) 